\title{
Phenotypic Correlations among the Negative Energy Balance Indicators and Milk Yield in High Yielding Murrah Buffaloes
}

\author{
A. Nagarjuna Reddy ${ }^{1}$, CH. Venkata Seshiah², K. Sudhakar ${ }^{1}$, \\ D. Srinivasa Kumar ${ }^{3}$ and P. Ravi Kanth Reddy ${ }^{4}$ \\ ${ }^{1}$ Teaching Assistant, CVSc, SVVU, Proddutur, AP - 516 360, India \\ ${ }^{2}$ Department of ILFC, ${ }^{4}$ Dept. of Animal Nutrition, NTRCVSc, SVVU, Gannavaram, \\ A.P - 521 102, India \\ ${ }^{3}$ Krishi Vigyan Kendra, Guntur - 522 034, Andhra Pradesh, India \\ *Corresponding author
}

\section{A B S T R A C T}

The objective of the present study was to determine the phenotypic correlations among the physical indicators, blood metabolites and 6\% FCM yield in high yielding Murrah

\section{Keywords}

Correlation

coefficients,

Negative energy

balance, $6 \%$

FCM yield,

Murrah buffaloes.

Article Info

Accepted:

23 June 2017

Available Online:

10 July 2017
Buffaloes. During the dry period, Body weight (BW) showed a significant positive correlation with Body Condition Score (BCS) $(\mathrm{P}<0.01)$ and Serum Glucose (SG) concentration $(\mathrm{P}<0.05)$, and negative correlation with serum non esterified fatty acids (SNEFA) $(\mathrm{P}<0.01)$ concentration. The same correlation pattern continued up to calving, except for SNEFA concentration which did not show any relation with BW and BCS. Later, 6\% Fat corrected milk yield $(\mathrm{FCMY})$ negatively correlated $(\mathrm{P}<0.05)$ with $\mathrm{BCS}$ at $30 d$ postpartum, followed by a strong positive $(\mathrm{P}<0.01)$ correlation with $\mathrm{BCS}, \mathrm{BW}$, and SG levels at $60 \mathrm{~d}$ postpartum. Although non significant, SG showed a negative correlation with $6 \%$ FCMY at calving, followed by a positive $(\mathrm{P}<0.01)$ and negative $(\mathrm{P}<0.01)$ correlation at 60 and 90 d postpartum, respectively. Further, a trend of decreased $6 \%$ FCMY and increased SG concentration is observed at $90 \mathrm{~d}$ postpartum owing to a negatively correlated SG levels with 6\% FCMY. The strong correlations observed among the serum metabolites and physical indicators evidence the potentiality of BCS, BW, SNEFA, SG levels and 6\% FCMY in anticipating the total milk yield and metabolic diseases induced by negative energy balance in high yielding Murrah Buffaloes.

\section{Introduction}

The transition period, a critical determinant of productivity and profitability in dairy farming, allows the animal to enter from a pregnant non-lactating to lactating nonpregnant state. The period is also accompanied with several physiological and biochemical changes exerting stress to animals and thus making them more susceptible to various metabolic and infectious diseases (Goff and Horst, 1997;
Mallard et al., 1998) resulting in monetary losses to dairy farmers. Besides, the characterized negative energy balance is associated with increased risk of metabolic disorders like Ketosis, retention of placenta and Downer cow syndrome after calving, thus reducing the milk production. Dairy animals are unique in their behavior of adaptation to the negative energy balance caused due to the homeorrhetic partition of energy for 
production maintenance (Reddy et al., 2016). The levels of circulating metabolites (SNEFA and $\mathrm{SG}$ ) and physical indicators of energy losses (BW and BCS) are considered as main principal indicators of negative energy balance, but very limited works were done to quantify their interrelation in buffaloes. Further, a total $57 \%$ of the world's Buffalo population resides in India, and it was hypothesized that Indian coastal region is dominated by buffaloes over other livestock species, as they are more able to tolerate high humid climatic condition existing in the region (Raju et al., 2017). Among the Indian buffaloes, the Murrah breed, a strain of water buffalo (Bubalus bubalis) is the finest genetic material of milk-producing buffalo not only in India but also probably in the world. Due to the higher genetic potentiality, this breed has been extensively used throughout India to upgrade non-descript buffalo stock to improve the milk production. Consequently, breeding these buffaloes in southern India peninsular region is a common phenomenon; and the hot and humid climatic regions characterizing the region may affect their performance and adaptability, especially to transition stress and negative energy balance. So, a study was conducted in high yielding Murrah buffaloes, out of their home tract (brought from Haryana), to know the extent of relationship between SNEFA, SG, BW, BCS and 6\% FCMY.

\section{Materials and Methods}

Forty eight multiparous Murrah buffaloes allotted to various dry period lengths were selected for the study from organized private buffalo farms located at Veeravalli village, Krishna District, Andhra Pradesh state. The BW and BCS recording; and collection of blood samples from jugular vein were done at the time of drying, calving, and 30, 60, and 90 $\mathrm{d}$ postpartum periods. The buffaloes were fed individually with concentrate mixture $(1 \mathrm{~kg}$ for maintenance, $1 \mathrm{~kg}$ for $2 \mathrm{~kg}$ milk production, and $1.5 \mathrm{~kg}$ in last 30 days pregnancy to meet the fetus requirements) along with adlibitum Hybrid Napier, and $4 \mathrm{~kg}$ Paddy straw. The CM was prepared by using locally availably ingredients (i.e., Maize, DORB, Soybean meal, sunflower cake, urea, mineral mixture and salt @ 33.25, 34, 18.75, $10,1,2$, and 1 percent respectively). Proximate analysis was done as per the AOAC (2007), and forage fibre fractions according to Vansoest et al., (1991).

\section{Determination of body weight}

Body weights of Murrah buffaloes were determined at the time of dry off, $30 \mathrm{~d}$ before the expected calving, at the time of calving and 30, 60 and $90 \mathrm{~d}$ postpartum by using Shaeffer's formula (Sastry et al., 1983).

Body weight $($ Pounds $)=\mathrm{LG}^{2} / 300$

Where, $\mathrm{L}=$ Length of the animal in inches, and $\mathrm{G}=$ Heart girth of the animal in inches.

( 1 inch $=2.5 \mathrm{cms}$ and $1 \mathrm{~kg}=2.5$ pounds)

The body length of Murrah buffaloes was measured using a measuring tape from the point of shoulder to the point of pin bone. The heart girth was measured by drawing the measuring tape around the area behind front legs, a point slightly behind the shoulder blade, down the fore-ribs.

\section{Assessment of body condition score}

BCS of the buffaloes was determined at the time of dry off, 30 days before expected calving and 30, 60 and 90 days postpartum using BCS scale developed by Anitha et al., (2010).

The score card was designed based on the amount of fat reserves at eight skeletal check points by vision and palpation. The skeletal 
check points were identified based on the anatomical features and carcass fat reserves. Based on the amount of fat reserves the scores were prioritized on a 1 to 5 scale of the new BCS proposed. The new BCS chart for condition scoring on a 1 to 5 scale using 0.5 increments was prepared. These check points include:

i. Tail head to pin bones

ii. Spinous processes of the lumbar vertebrae

iii. Depression between the spinous and transverse processes

iv. Transverse processes of lumbar vertebrae

v. Point between 12th and 13th ribs

vi. Sacral crest

vii. Depression between sacral crest and hooks

viii. Depression between hooks and pins

NEFA estimation was carried out as per Falholt et al., (1973). Determination of SG levels was done by Erba Mannheim Glucose kits (Trinder's method, End point Assay). The $6 \%$ FCM was calculated using the formula (Rice et al., 1970); 6\% FCM $=0.308 \times$ Total Milk Yield +11.54 x Total Fat Yield (kg).

\section{Statistical analysis}

The estimated data of BW, BCS, SG, SNEFA and $6 \%$ FCM levels was subjected to ANOVA (Snedecor and Cochran, 1994) using software package SPSS version 17.0, and differences in mean were assessed by using Duncan's multiple range test (Duncan, 1955). Data was analyzed for statistical correlation (two tailed test of significant) for the estimated parameters during pre and postpartum periods using Pearson coefficient.

\section{Results and Discussion}

The estimated percentages of $\mathrm{CP}, \mathrm{EE}, \mathrm{CF}$, and NDF were 6.23, 1.84, 23.11, and 69.09; 3.54,
1.65, 42.58, and 69.80; and 21.3, 9.14, 5.98, and 14.88 in Hybrid Napier, Paddy Straw, and $\mathrm{CM}$, respectively.

The mean values of BW, BCS, SG, SNEFA and 6\% FCMY during drying, calving, and 30, 60 and 90 days postpartum periods are presented in table 1 . The correlation coefficients among the physical indicators, blood metabolites and 6\% FCMY during pre and post calving periods are shown in table 2 and 3, respectively. BW was strongly correlated with $\mathrm{BCS}(\mathrm{P}<0.01)$ during both pre and post calving periods, with highest correlation at $90 \mathrm{~d}$ postpartum. BCS reflects $\mathrm{BW}$ and in turn considered as a more reliable parameter than BW to know the energy mobilization, as the former measurement accounts subcutaneous fat in dairy animals. The absolute amount of BCS loss is a good indicator of nutritive status and correlates well with the high incidence of reproductive and metabolic diseases (Kalaitzakis et al., 2007).

The evaluated physiological range of BCS throughout the course of study was from 3.31 to 4.00 , and 3.32 to 4.73 in pre and postpartum periods, respectively. Further, the BCS loss from drying to calving (0.62 points) is in the range of the physiologically acceptable loss (0.6 to 0.7 points), as indicated by samanc et al., (2010). BW was positively correlated with SG concentrations, at pre $(\mathrm{P}<0.05)$ and post calving $(\mathrm{P}<0.01)$ periods. Low dry matter intake (DMI) and increased production potential after calving during postpartum period decreases both BW and SG levels. Even though gluconeogenesis is a continuous process in ruminants and they do not solely depend on dietary glucose levels, reduced DMI around parturition decreases SG levels, as Propionic acid is a major gluconeogenic precursor in ruminants contributing up to $73 \%$ of the total glucose synthesized (Reddy et al., 2016). 
Correlation coefficients during precalving period

During the dry period, BW showed a significant positive correlation with BCS $(\mathrm{P}<0.01)$ and $\mathrm{SG}$ concentration $(\mathrm{P}<0.05)$, and negative correlation with SNEFA $(\mathrm{P}<0.01)$ concentration. The same correlation pattern continued up to calving, except for SNEFA concentration which did not show any relation with BW and BCS. In the last trimester of pregnancy, fetus grows enormously exerting pressure on the rumen and sending negative signals to the satiety centre of hypothalamus on voluntary feed intake (Reddy et al., 2016), thus reducing the DMI, and so the BW, BCS, and SG levels. The prepartum correlation phenomenon might also be explained by the rapidly increased SNEFA concentration in parallel to BW and BCS, due to the excessive body reserves mobilization in relation with decreased DMI and increased energy requirement for the growing fetus.

Table.1 Mean BW, BCS, SG, SNEFA and 6\% FCMY during drying, calving, and 30, 60 and 90 days postpartum periods

\begin{tabular}{cccccc}
\hline \hline Period & BW & BCS & SG & SNEFA & $6 \%$ FCMY \\
\hline At Drying & $577.31^{\mathrm{b}} \pm 4.07$ & $3.76^{\mathrm{a}} \pm 0.024$ & $62.56^{\mathrm{d}} \pm$ & $395.21^{\mathrm{a}} \pm$ & - \\
& & $4.33^{\mathrm{c}} \pm$ & $53.84^{\mathrm{c}} \pm$ & $634.39^{\mathrm{b}} \pm$ & \\
At Calving & $625.7^{\mathrm{c}} \pm 3.67$ & 0.019 & 0.36 & 4.18 & - \\
At 30 d & $564.12^{\mathrm{ab}} \pm$ & $4.00^{\mathrm{b}} \pm$ & $49.76^{\mathrm{b}} \pm$ & $732.73^{\mathrm{c}} \pm$ & $14.08^{\mathrm{a}} \pm$ \\
postpartum & 3.86 & 0.029 & 0.45 & 5.83 & 0.17 \\
At 60 d & $557.25^{\mathrm{a}} \pm 4.14$ & $3.83^{\mathrm{a}} \pm 0.034$ & $45.55^{\mathrm{a}} \pm$ & $774.92^{\mathrm{d}} \pm$ & $22.19^{\mathrm{c}} \pm$ \\
postpartum & & & 0.43 & 6.28 & 0.32 \\
At 90 d & $551.55^{\mathrm{a}} \pm 4.18$ & $3.74^{\mathrm{a}} \pm 0.037$ & $50.18^{\mathrm{b}} \pm$ & $756.73^{\mathrm{d}} \pm$ & $20.00^{\mathrm{b}} \pm$ \\
postpartum & & & 0.38 & 6.51 & 0.34 \\
\hline \hline
\end{tabular}

*Each value is a mean of 48 observations $(n=48)$

${ }^{\text {abcd }}$ Values bearing different superscripts in columns differ significantly $(\mathrm{P}<0.05)$.

Table.2 Pearson correlation coefficients of BW, BCS, SG and SNEFA during precalving period

\begin{tabular}{|c|c|c|c|c|c|c|c|c|}
\hline & \multicolumn{4}{|c|}{ At Dry Period } & \multicolumn{4}{|c|}{ At Calving } \\
\hline & BW & $\mathrm{BCS}$ & SG & SNEFA & BW & BCS & SG & SNEFA \\
\hline BW & 1 & $.531 * *$ & $.148 *$ & $-.366^{* *}$ & 1 & $.427 * *$ & $.345^{*}$ & -.041 \\
\hline BCS & & 1 & -.060 & $-.339 *$ & & 1 & .233 & .000 \\
\hline SG & & & 1 & $-.146^{*}$ & & & 1 & $-.393 * *$ \\
\hline SNEFA & & & & 1 & & & & 1 \\
\hline
\end{tabular}


Table.3 Pearson correlation coefficients of BW, BCS, SG and SNEFA during post calving period

\begin{tabular}{|c|c|c|c|c|c|c|c|c|c|c|c|c|c|c|c|}
\hline & \multicolumn{4}{|c|}{ At $30 \mathrm{~d}$ Postpartum } & \multicolumn{6}{|c|}{ At 60 d Postpartum } & \multicolumn{5}{|c|}{ At 90 d Postpartum } \\
\hline & $\mathrm{BW}$ & BCS & $\begin{array}{c}\text { Serum } \\
\text { Glucose }\end{array}$ & $\begin{array}{l}\text { Serum } \\
\text { NEFA }\end{array}$ & $\begin{array}{c}6 \% \\
\text { FCMY }\end{array}$ & BW & $\mathrm{BCS}$ & $\begin{array}{c}\text { Serum } \\
\text { Glucose }\end{array}$ & $\begin{array}{l}\text { Serum } \\
\text { NEFA }\end{array}$ & $\begin{array}{c}6 \% \\
\text { FCMY }\end{array}$ & BW & BCS & $\begin{array}{c}\text { Serum } \\
\text { Glucose }\end{array}$ & $\begin{array}{l}\text { Serum } \\
\text { NEFA }\end{array}$ & $\begin{array}{c}6 \% \\
\text { FCMY }\end{array}$ \\
\hline BW & 1 & $.659 * *$ & $.374 * *$ & $-.441 * *$ & -.049 & 1 & $.705 * *$ & $.396 * *$ & $-.569 * *$ & $.510 * *$ & 1 & $.711 * *$ & $.593 * *$ & $-.584 * *$ & $.692 * *$ \\
\hline $\mathrm{BCS}$ & & 1 & $.635^{* *}$ & $-.651 * *$ & $-.297 *$ & & 1 & $.660 * *$ & $-.761 * *$ & $.735^{* *}$ & & 1 & $.792 * *$ & $-.807 * *$ & $.836 * *$ \\
\hline SG & & & 1 & $-.735 * *$ & -.154 & & & 1 & $-.713 * *$ & $.607 * *$ & & & 1 & $-.729 * *$ & $-.746^{* *}$ \\
\hline SNEFA & & & & 1 & .125 & & & & 1 & $.732 * *$ & & & & 1 & $-.746 * *$ \\
\hline $6 \%$ FCMY & & & & & 1 & & & & & 1 & & & & & 1 \\
\hline
\end{tabular}

** $\mathrm{P}<0.01, * \mathrm{P}<0.05$ 


\section{Correlation coefficients during post calving period}

The 6\% FCMY had a negative significant $(\mathrm{P}<0.05)$ correlation with $\mathrm{BCS}$ at $30 \mathrm{~d}$ postpartum, followed by positive $(\mathrm{P}<0.01)$ correlation with BCS, BW, and SG at $60 \mathrm{~d}$ postpartum. During the initial days of early lactation phase (30 d period), both lowered DMI and increased milk production leads to excessive mobilization of body reserves, thus causing an excessive loss of BCS which harmonizes with higher milk yield. Similarly, Khan et al., (2011) reported the excessive body reserves mobilization, higher SNEFA levels and decreased BCS during early lactation phase. On the contrary, Melendez et al., (2002) observed a peak level of NEFA concentration at parturition with a slow decrease after 3 days postpartum. Higher SNEFA levels in the present study might be a factor of higher milk production and environmental stress, as all the buffaloes under experiment were summer calvers. The positive correlation observed at $60 \mathrm{~d}$ postpartum might be related to increased intake, thereby increasing the BCS, BW, SG and 6\% FCMY, and decreasing SNEFA concentration in parallel.

Although non significant, SG showed a negative correlation with 6\% FCMY at calving, followed by a positive $(\mathrm{P}<0.01)$ and negative $(\mathrm{P}<0.01)$ correlation at 60 and $90 \mathrm{~d}$ postpartum, respectively. Glucose might be primarily utilized in mammary gland to support increased lactation owing to diminished serum glucose levels, especially in the first phase of early lactation. The SG concentration $(\mathrm{mg} / \mathrm{dl})$ showed a decreased trend from the calving to 60 days postpartum followed by an increased trend from 60 to 90 days postpartum; higher SG levels favor lipogenesis over lipolysis (Herdt, 2000), further reducing the plasma NEFA levels.
A trend of decreased 6\% FCMY and increased SG concentration is observed at 90 $\mathrm{d}$ post partum owing to a negatively correlated SG levels with 6\% FCMY. The physiological changes occurred after 60 days postpartum due to the increased DMI and a downfall in peak milk production (Obtained at 60 days postpartum), might have decreased the stress, thereby increasing the SG levels and decreasing the SNEFA concentrations.

In conclusion, the observed patterns of the variables indicate that the buffaloes were in negative energy balance, especially during the initial days of early lactation phase. Further, a strong linear correlation was observed between 6\% FCMY and BW, BCS, SG, and SNEFA values, indicating the potentiality of the serum metabolites and physical indicators in predicting negative energy balance and milk yield in high yielding Murrah Buffaloes.

\section{References}

Anitha, A., Sarjan Rao, K., Suresh, J., Srinivasa Moorthy, P., Reddy, Y. and Reddy, K. 2010. Development of the body condition score system in Murrah buffaloes: Validation through ultrasonic assessment of body fat reserves. $J$. Vet. Sci., 11: 1-8.

AOAC. 2007. Official Methods of Analysis, Association of official Analytical chemists, $13^{\text {th }}$ edn., Washington, D.C, USA.

Duncan, D.B. 1955. Multiple range and multiple F tests. Biometrics, 11: 1.

Falholt, K., Lund, B. and Falholt, W. 1973. An easy colorimetric micro method for routine determination of free fatty acids in plasma. Clin. Chim. Acta., 46: 105111.

Goff, J.P., Horst, R.L. 1997. Effects of the addition of potassium or sodium, but not calcium, to prepartum rations on milk fever in dairy cows. J. Dairy Sci., 
80: $176-186$.

Herdt, T.H. 2000. Ruminant adaptation to negative energy balance. Influences on the etiology of ketosis and fatty liver. Vet. Clin. North Am. Food Anim. Pract., 16: 215-230.

Kalaitzakis, E., Roubies, N., Panousis, N., Pourliotis, K., Kaldrymidou, E. and Karatzias, H. 2007. Clinicopathological evaluation of hepatic lipidosis in periparturient dairy cattler. J. Vet. Int. Med., 21: 835-845.

Khan, H.M., Mohanty, T.K., Bhakat, M., Raina, V.S. and Gupta, A.K. 2011. Relationship of blood metabolites with reproductive parameters during various seasons in Murrah buffaloes. Asian Aust. J. Anim. Sci., 24(9): 1192-1198.

Mallard, B.A., Dekkers, J.C., Ireland, M.J., Leslie, K.E., Sharif, S., Lacey, C., Wagter, V.L., Wilkie, B.N. 1998. Alteration in immune responsiveness during the peripartum period and its ramification on dairy cow and calf health. J. Dairy Sci., 81: 585-595.

Melendez, P., Donovan, A., Risco, C.A., HaLL, M.B., Littell, R. and Goff, J. 2002. Metabolic responses of transition Holstein cows fed anionic salts and supplemented at calving with calcium and energy. J. Dairy Sci., 85: 10851092.

Raju, J., Reddy, P., Reddy, A., Kumar, C., Hyder, I. 2017. Livestock feed resources in surplus rainfall Agro ecological zones of Andhra Pradesh:
Requirement, availability and their management. Int. J. Livestock Res., 7(2): 148-163.

Reddy, P.R.K., Raju, J.K., Reddy, A.N., Reddy, P.P.R. and Hyder, I. 2016. Transition period and its successful management in dairy cows. Ind. J. Nat. Sci., 7(38): 11691-11699.

Rice, V.A., Andrews, F.N., Warnwick, K. and Legates, J.E. 1970. Breeding and Improvement of farm animals, 6th ed. Tata, Mcgrah Hill Publishing Company Ltd. Bombay, India.

Samanc, H., Kirovski, D., Jovanovic, M., Vujanac, I., Bojkovic kovacevic, S., Jakicdimic, D., Prodanovic, R. and Stajkovic, S. 2010. New insights into body condition score and its association with fatty liver in Holstein dairy cows. Acta veterinaria (Beograd), 60: 525540.

Sastry, N.S.R., Thomas, C.K. and Sing, R.A. 1983. Shaeffers formula for body weights of cattle described in farm animal management and poultry production 5th edition, Vikas publishing house India.

Snedecor, G.W. and Cochran, W.G. 1994. Statistical methods, 8th edn, Iowa state University press, Ames, Iowa USA50010.

Van Soest, P.J., Robertson, J.B. and Lewis, B.A. 1991. Methods for dietary fiber, neutral detergent fiber and non-starch polysaccharides in relation to animal nutrition. J. Dairy Sci., 74: 3583-3597.

\section{How to cite this article:}

Nagarjuna Reddy, A., CH. Venkata Seshiah, K. Sudhakar, D. Srinivasa Kumar and Ravi Kanth Reddy, P. 2017. Phenotypic Correlations among the Negative Energy Balance Indicators and Milk Yield in High Yielding Murrah Buffaloes. Int.J.Curr.Microbiol.App.Sci. 6(7): 2641-2647. doi: https://doi.org/10.20546/ijcmas.2017.607.312 